\title{
Immunological Approaches and Different Strategies for Vaccine Development Against SARS-COV-2
}

\author{
Muhammed Babakir-Mina \\ Medical Laboratory Department \\ Technical College of Health \\ Sulaimani Polytechnic University \\ Sulaimani, Iraq \\ m.babakir@yahoo.com
}

Article Info
Volume 5 - Special Issue: $4^{\text {th }}$
International Conference on the Health
and Medical Science : Medical
Researches Improve Life Quality
(ICHMS 2020)
DOI:
10.24017/science.2020.ICHMS2020.10
Article history:
Received: 12 September 2020
Accepted: 24 September 2020

\section{Keywords:}

SARS-COV-2, immunity, IgG, IgM, vaccines, Serum therapy

\begin{abstract}
Globally, SARS-CoV-2 outbreak is considered as pandemic viral infection by the World Health Organization (WHO). In the immunological response aspect, a very limited understanding has been progressed, mainly innate and adaptive immunity responses toward the virus. SARS-COV2 causes severe respiratory disease and sometimes ended with the death. The body of the patients has ability to develop the immunity to cure the patient and more importantly both humoral and cellular immunity have studied against SARS-COV-2. There are different immune responses against the viral infection as it has seen in other previous diseases such as SARS-COV and MESR. On the base on immune response detected in recovered patients, scientists have started to develop the vaccines. Moreover, there are different strategies that used by researchers and pharmacological companies to develop vaccines including attenuated or killed viruses, RNA of a spike protein, and vector expressing a particular protein of the virus. The common antibodies have detected to work against SARS-COV-2 in sera of infected or recovered patients are immunoglobin $G(\operatorname{IgG})$ and immunoglobin $M(\operatorname{Ig} M)$. The sera of patients recovered from COVID-19, after tittering of immunoglobulins (IgG titer) can be used for either treatment of disease or prophylaxis of infection by SARS-COV-2. This study gives an update on the current immunological approaches and vaccination strategies for the emerging SARS-COV-2, and discusses the challenges and hurdles to overcome for developing efficacious vaccines against this dangerous pathogen.
\end{abstract}




\section{INTRODUCTION}

Anatomically, respiratory tract is an opened tube divided into upper and lower parts; the upper respiratory tract consists of the nose, mouth and pharynx, while trachea, bronchi and lungs are a part of the lower respiratory tract, which lining by epithelial tissues. The epithelial tissues in the respiratory system serve as a barrier layer that separate and protect the internal tissues from outer environment, provides a marvelous first lines of body defense against pulmonary diseases by pathogens. Goblet cells seems among ciliated columnar epithelial cells, along with club and tuft cells secret a surfactant substance, together produce impermeable barrier via construction of tight junctions occupied the tope surface of the epithelial cells [1][2]. The action movement upward of the mucocilla is another element of the epithelial tract, which accelerates clearance of trapped particles pulled to upward of the respiratory tract then, eliminated or facilitates by coughing [3]. Damaging of epithelial tissues, tight junctions and changing in the permeability of epithelial cell membrane by air pollutant or allergen and infections by respiratory viruses. Additionally, the epithelial of respiratory tract is immunologically active; it has an essential function for regulation and immune response activation in lung [4].

Pulmonary epithelial cells can detect Pathogen Associated Molecular Pattern (PAMP) in action of expressing Pattern-Recognition Receptors (PRR) [5], also epithelial cell has the ability to secrete variety of humoral agents such as cytokines and chemokines which associated with local immunity leads to eliminate of dead cells via apoptosis and actions of proinflammatory cells, this process done by intracellular signaling which mediates by GTPase Ras-related C3 botulinum toxin substrate 1 (Rac1). Rac1 regulate secretion of several cytokines of bronchia epithelial cells, such as IL-10 and IL-33 it may have crucial roles in regulation of allergic reactions. In addition, the airway epithelial cells able to secret of different antimicrobial molecules, such as lysozyme, complement proteins, collectins and defensins. In the response of foreign particles most of the molecules produced and secreted by pulmonary epithelial cells can regulate and generate immune responses, activate the cells of both innate and adaptive system [6] [7].

The respiratory systems continuously exposure to the exterior environment, alveolar epithelial cells are a target of viral infections includes coronaviruses $(\mathrm{CoV})$ [8]. $\mathrm{CoV}$ is an enveloped non-segmented plus single stranded RNA (ssRNA) virus, the entire genome size ranged from 26 to 32 kilobases, double stranded RNA (dsRNA) produces as an intermediate of synthesize viral RNA genome during viral replication in the cytosol of infected cells [9]. WHO announced on Severe Acute Respiratory Syndrome Coronavirus 2 (SARS-CoV-2) as a pandemic that leads to novel coronavirus disease 2019 (COVID-19) [10].

In case of SARS-CoV-2 infected patients, the histopathological examination of airway show non-specific inflammatory responses includes; infiltration of inflammatory cells (such as neutrophils, monocytes, and eosinophils) and edema, also determine serious alveolar epithelial cells exfoliation and found widening and damaging in alveolar septa. Pathologically, CoV infection seems leads to degeneration, hyperplasia and infiltration, further pulmonary interstitial arteriolar walls destruction, demonstrated nonspecific inflammatory responses have been a critical role all over the viral infection [11]. While SARS-CoV infects a person, host immune response triggered against virus.

Middle East respiratory Syndrome Coronavirus (MERS-CoV) can affect a variety of cells in the human body, such as moncytes, $\mathrm{T}$ cells and it may be infected DCs also. The ability of MERS-CoV infections a wide range of cells may be refer to presence the dipeptidyl peptidase- 
4 rceptor on the surfces cytoplasmic membrane of activated white blood cell, while both SARS-CoV and SARS-CoV-2 consider the angiotensin-converting enzyme 2 (ACE2) as a speecific receptor [12]. ACE2 receptor expressed mostly in the type-2 alveolary in the lungs, the study reported that $\mathrm{CoV}$ capable to infect macrophage and T-lymphocytes directly and it is a major factor of virus mediated pathogenesis [13] [14].

Innate immunity can recognize the viral dsRNA by PPR, such as Toll like receptors (LTRs) and Retinoic acid-inducible gene I (RIG-I)-like receptors (RIG- I ) trigger and activate interferon regulatory factors (IRF) which initiate interferon (IFN) type I production includes IFN- $\alpha$ and IFN- $\beta$, recruit phagocytic cells such as macrophage and dendritic cells (DCs) natural killer cells cytotoxic T-lymphocytes (CTL) followed by elimination of the virus [15] 16] [17]. DCs is one of the professional antigen presenting cells (APCs) capable to engulf viruses migrate to lymphoid tissues and display viral particles to helper T-lymphocytes via aids of major histocompatibility class II (MHC II ) [18], DCs have great impact in both cellular and humoral immunity responses, they obviously able to induce the activation of $\mathrm{B}$ and T lymphocytes, hence link innate and adaptive immunity [19] [20]. Consequently DCs is one of the target invasions by microbes, such as HIV drive different mechanisms to manipulate and effects on the functions of DCs, eventually HIV escape from the immune system and facilitating cell to cell diffusion [21]. This study gives a base for more further investigation for immunological protection against SARS-CoV-2, and to understand the pathogencity of COVID-19, and more importantly for the development of efficient vaccine against this new pandemic viral infection.

\section{Humoral Immune Responses}

The cytokine of production is affected when patients are infected by MERS and SARS coronaviruses due to the impairment of the function of innate cells of immunity in the infected host [22]. The entry of SARS coronavirus is facilitated via spike (S) protein of the virus. Receptor binding domain (RBD) of the spike protein which is located in S1 subunit of the spike is important for the attachment steps of viral replication. Furthermore, the protease enzyme is priming the S protein of the SARS COV2 helping cleaving of the spike into S1/S2. This helps the fusion of the virus membrane to the host receptor membrane. This process is held by S2 of the spike docks on ACE2 (angiotensin-converting enzyme 2) receptor and then it helps priming of the spike proteins for entry process via Transmembrane protease, serine 2 $[23,24]$. T and B immune cells responses create important parts of the adaptive immune response. Humoral immunity through producing large amount of circulating antibodies play a vital roles in the protection of the infected host in late stages and also in future protection of recurrent infection. In the previous outbreak of SARS-CoV, all structural proteins of the virus, M, N, S and E, were mapped by epitopes of the B and T cells [25]. It's revealed that infected patients carry a strong human immune response after being infected by SARS-CoV [26]. The pattern of antibody production, $\operatorname{IgM}$, IgG, and $\mathrm{IgA}$, of SARS-CoV2 is similar to other coronavirus infections. At the 4-8 days of the beginning of the infection and appearing symptoms, the host creates the first $\mathrm{Ab}$ against SARS-CoV $\mathrm{N}$ protein which is made by $\mathrm{B}-$ cells [27]. Cleaning of blood from SARS cove is mainly depends on normalizing Ab, IgGs. During convalescent stage of the disease, IgG peak to the highest amount and it will drop down during recovery [28]. It is difficult to immune system to mutualize $\mathrm{S}$ protein when its masked by $\mathrm{N}$-glycan because it has a structure called $\mathrm{S}$ protein glycan which works as a shield to be not recognized easily by Abs. But, less saturated S protein with glycan is less protected from Abs and it becomes a target of IgGs [29, 30,31].

Infected ferrets had serum neutralizing antibodies at 12 days post-infection, but so far, no rechallenge experiments have been reported. Rhesus macaques are susceptible to SARS-CoV-2, where infection causes a respiratory disease lasting 8-16 days, with detectable high viral loads in the nose, throat and bronchoalveolar lavages. All animals seroconverted to the spike protein and showed neutralizing antibodies by 10 days post-infection, in another study in rhesus macaques, two animals were re-challenged with virus at 28 days from the primary infection, when anti-spike immunoglobulins were detectable and neither became infected, by this way, antibody responses increased against SARS-S after vaccination or infection of the host which 
gives some protection level against SARS-CoV-2 [32,33,34]. Investigation was done by [35]. During epidemic of the virus infection, IgG saturated serum was used to treat debilitated patients. This convalescent serum which is useful for treatment of the infected hosts by different viruses which recorded in different times of history against different viruses including H1N1 2009 pandemic infection, the West African Ebola epidemic in 2013 [37]. Investigation was done by [35]. During epidemic of the virus infection, IgG saturated serum was used to treat debilitated patients. This convalescent serum which is useful for treatment of the infected hosts by different viruses which recorded in different times of history against different viruses including H1N1 2009 pandemic infection, the West African Ebola epidemic in 2013 [37]. This covalence serum was tests successfully in SARS-CoV infection which works gains $\mathrm{S}$ protein of the virus [38]. On the other hand, pre-prepared monoclonal $\mathrm{Ab}$ is another and a good choice to cure and control SARS-CoV2 pandemic and it can be used as a vaccine used for rapid response [39]. When vaccine therapy is not available now, the covalence serum of recovered patient is the most successful way of emergency treatment for cleaning of the virus in the infected hosts and it has been tried in different countries [40,41]. This is approved to use by The Food and Drug Administration (FDA) for the current therapy of SARS-CoV2 and it can be taken from recovered patients who passed 3 weeks after the last negative PCR test for the virus. The important step of this treatment is availability of the serum donors who are recovered from the infection [42].

\section{The roles of IgA antibody in COVID-19 infection}

The IgA antibody is the major class secreted in mucosal secretion for defense against microorganisms entering the body through mucous membranes of the respiratory tract, gastrointestinal tract, and genitourinary tract. This secretory $\operatorname{IgA}(\mathrm{SIgA})$ presents in body secretions protects the body from pathogenic adhesion to mucous membranes [43].

On one hand the antibody immune response and inactivate SARS-CoV-2, on the other hand, antibodies can form immune complexes with viral particles and participate in pulmonary inflammatory response which exacerbate or prolong the COVID-19 infections [44]. Currently, COVID -19 infection is suggested to follow antibody dynamics similar to other respiratory viral infections; the IgM antibody is the first appear in antibody response, but class switching can result in the formation of IgA antibodies specific to SARS-CoV-2 within few days after the appearance of the symptoms. These IgA antibodies are produced by plasma cells in the lamina propria adjacent to the mucosa in the respiratory lining. The IgA antibody is the main antibody fights against respiratory viruses in respiratory secretions. It can bind to SARS-CoV2 in respiratory tract and thus prevent viral attachment to respiratory epithelium [45]. Systematic studies on IgA antibodies in Covid-19 are lacked, as most of the studies are focusing on IgM and IgG antibodies which are associated with recent and previous infections respectively [46]. With the current global challenges due to COVID-19 infections and with more than 1.16 million worldwide, there is a need for understanding the IgA antibody response against SARS-CoV-2 and its effectiveness in controlling infections with this virus.

The IgA is positive in about 6 days after the onset of clinical features, which is the same time for IgM seroconversion, thus after one week of COVID-19 infection, both IgA and IgM antiCOVID-19 antibodies are detectable in blood of the patients [47]. Then these two antibodies are decline within 3 weeks up to one month after the start of symptoms [48]. While IgG antiCOVID-19 antibodies detected within blood in the period of 10-18 days after the clinical features and continue for months [46].

\section{Vaccine Development and Strategies}

COVID-19 is a new virus to human to understand its structure and behavior and the immunological responses to this virus have not completely understood. Strategies to develop a successful vaccine are not clear until now. Therefore, it is crucial to work on developing vaccines on different platforms at the same time. Therefore, from appearing COVID-19 at the beginning, all of the world countries are competing each other to develop a successful vaccine. Till now there are a number of vaccine candidates which are in progressing and aims to be useful in the clinical developments [50]. However, it is not clear whether generate it can be safe and affective immune response against COVID-19, therefore the best strategies is 
required and the expectation of successful vaccine is important in next years. Several attempts have undergoing for COVID-19 vaccine development to stop and reduce the viral transmission and mortality. The most common attempt of vaccine is to induce immunity against the Spike protein of the virus [51]. Until July, 2020, under the strategy of developing vaccines, 158 vaccines are on the way and 135 of them reached in the pre-clinical and clinical tests and the stages of developments. At the time of this study, many companies has vaccine developments and they are in advanced phases of I/II clinical trials such as Inovio, Inc. (INO4800); CanSino Biologicals (Ad5-nCoV); Moderna (mRNA-1273); University of Oxford (ChAdOx1) and ShinzenGeno-Immune Medical Institute [52]. There are different ways of building vaccines such as preparing vaccine from attenuated virus or inactivated (killed) virus. Recent development of vaccine can be generated from preparing a protein of the virus such as virus-like particles, viral vector expressing the protein of interest (replicating and nonreplicating) [53]. To improve the immunogenicity, different technologies of adjuvant of vaccines such as AS03 (GSK), CpG 1018 (Dynavax), MF-59 (Novartis) are under the construction of vaccine development [54]. The immuno-informatics methods are another way for epitope identification of COVID-19. This has useful role in recognizing epitopes of TCells for proteins of COVID-19 such as of B-cell and cytotoxic T cells [55,56].

\section{Advancements in Vaccine Production and Natural Immunity}

The major trouble is producing vaccine in a short period of time is testing safety and mass production of vaccine to all. This may take very long time to reach to the point of to solve this problem at the first step. According to the report of WHO, 70 COVID-19 vaccine are under progress. The Kaiser Permanente Washington Health Research Institute was the first place who started producing corona virus vaccine. mRNA-1273 vaccine is one candidate made by the National Institute of Allergy and Infectious Diseases scientists and their collaborators at the biotechnology company Moderna. The phase 1 of clinical trial to the mentioned vaccine was supported and started by The Coalition for Epidemic Preparedness Innovations [57,58]. Another viral vaccine called S-protein vaccine is in progress. Jenner Institute at Oxford University with AstraZeneca pharmaceutical company have developed this vaccine.

It remains unclear to understand how immunity works against COVID-19. however, it is induced immunity using vaccine may be different from immunity come from the natural that depends on the natural invasion of the active viral agent. Therefore, importantly it is crucial for understanding development of natural immunity to help further understanding of vaccine inducing immunity using effective vaccine to become a strategy of choosing and select the best vaccine for therapeutic purposes. It is crucially important to understand how immune response works in different cases of patients such as patients with different clinical signs and also according to the severity of infection, severe cases, mild cases or even asymptomatic cases. Furthermore, it is important to understand natural immune responses in different stages of the disease such as whether it's in early stages of infection or in the late stages. In addition, the severity of infection according to ages should be understandable by understanding the reason why and how immune response is different from young people in elderly. It is believed that 40-70 of COVID-19 cases are going without clinical symptoms, asymptomatic or mild $[59,60]$. It is estimate that people who carry the virus without symptoms, significantly spreading the virus more that symptomatic patients [61]. On the other hand, mild patients or asymptomatic produces lower antibody (natural immunity) against the virus and that impedes the process of developing immunity in community and making herd immunity to be difficult to gain.

\section{Specific Antibodies and T Cell Mediated Immunity}

In most cases of this novel coronavirus infections, both IgM and IgG produce after one to two weeks of infection [62]. Although, it is still unclear how the T-Cell, and specific antibodies related to each other. But T-cell production and response is correlated with high levels of circulated antibodies in the blood of infected individuals $[63,64]$, and this is beneficial to treat infected patients with convalescent plasmas of recovered persons [65]. In the a study, it was revealed that the high level of neutralizing antibodies in the recovered patients is correlated to the severity of infections [66]. Same as other common cold diseases, the levels of neutralizing 
COVID-19 antibodies in most of infected cases were in few weeks of infection [66,67]. In addition, the level of neutralizing antibodies production in asymptomatic COVID-19 individuals is about the same as in symptomatic patients, but it is different in the time of decreeing antibody titer and it drops faster in asymptomatic patients [61]. The main target of immune system to produce neutralizing antibodies is spike (S) protein SARS-CoV2. Spike protein has two main domains, (S1) and (S2) domains. Receptor binding domain (RBD) of S protein locates in $\mathrm{S} 1$ domain of a spike protein which has important role in binding to host cells' ACE2 receptor [68]. SARS-CoV2 S protein has identical property by $88 \%$ with $\mathrm{S}$ protein in SARS-CoV, which enables both of them to bind cellular ACE2 with high affinity [68]. If the antibody catches the RBD S protein, directly block RBD of S with ACE2 receptor interaction. While, if antibodies catch the other regions of $\mathrm{S} 1$ or $\mathrm{S} 2$, prevent the conformational changes of $\mathrm{S}$ protein which inhibit the process of membrane fusion between the host cell and virus membrane $[69,70,71]$. The successful vaccination program of different viruses like Influenza viruses is largely depend on not only antibody production, but also $\mathrm{T}$ cell mediated and antibody mediated immunity to build affective protection. The same requirements are necessary for SARS- CoV-2 [67,72]. Furthermore, the important role of cytotoxic CD8+ $\mathrm{T}$ cells for viral clearance is completely understood when there are not enough neutralizing antibodies [73]. CD4 and CD8 are important for viral protection. It is revealed in a study that people who cured from Covid-19 infection have $100 \% \mathrm{~T}$ cells $+\mathrm{CD} 4$ which are specific to spike protein and 70\% T cells + CD8 which are specific to spike protein [64]. In pre-clinical study, its revealed that COVID-19 infection is related to suppression of innate immunity and late $\mathrm{T}$ cell activation during 2-12 days of virus incubation or in presymptomatic cases of infected person [74,75] and the same phenomenon was seen in to previous viral diseases, MERS and SARS. The high levels of T cells and protective antibodies have detected from individuals who recovered from severe COVID-19 cases, while people who recovered from mild cases of infection have larger number of $\mathrm{T}$ cells and CD8 in respiratory tracts $[63,64,76]$.

\section{CONCLUSION}

There are difference immune responses against this novel coronavirus as it has been seen in previous diseases such as SARS-COV and MESR. On the base on immune response detected in recovered patients, scientists started to develop vaccines. There are different strategies used by researchers and pharmacological companies to develop vaccines including attenuated or killed viruses, RNA of a spike protein, and vector expressing a particular protein of the virus. The common antibodies detected to work against COVID-19 in sera of infected or recovered patients are IgG and IgM. The sera of patients recovered from COVID-19, after tittering of immunoglobulins (IgG titer) can be used for either treatment of disease or prophylaxis of infection by SARS-COV-2.

\section{REFERENCE}

[1] T. Braciale, J. Sun, T. Kim, "Regulating the adaptive immune response to respiratory virus infection," Nature Reviews Immunology, 12, pp. 295-305, 2012.

[2] DANDEKAR, S. PERLMAN, "Immunopathogenesis of coronavirus infections: implications for SARS," Nature reviews immunology, 5, pp. 917-927, 2005.

[3] G. RADICIONI, R.CAO, J. CARPENTER, A. FORD, T. WANG, Y. LI, et al., "The innate immune properties of airway mucosal surfaces are regulated by dynamic interactions between mucins and interacting proteins: the mucin interactome," Mucosal immunology, 9, pp. 1442-1454, 2016.

[4] IWASAKI, , E. FOXMAN, R. MOLONY, "Early local immune defences in the respiratory tract"” Nature Reviews Immunology, 17, pp. 7, 2015.

[5] LAMBRECHT, H. HAMMAD, "The airway epithelium in asthma. Nature medicine," 18, pp.684, 2012.

[6] JUNCADELlA, A. KADL, A. SHARMA, Y. SHIM, A. HOCHREITER-HUFFORD, L. BORISH, et al., "Apoptotic cell clearance by bronchial epithelial cells critically influences airway inflammation," Nature, 493, pp. 547-551, 2013.

[7] IWASAKI, E. FOXMAN, R. MOLONY, "Early local immune defences in the respiratory tract," Nature Reviews Immunology, 17,pp. 7, 2017. 
[8] T. BRACIALE, J. SUN, T. KIM, "Regulating the adaptive immune response to respiratory virus infection," Nature Reviews Immunology, 12, pp. 295-30, 2012.

[9] S. PERLMAN, J. NETLAND, "Coronaviruses post-SARS: update on replication and pathogenesis. Nature reviews microbiology, 7, pp. 439-450, 2009.

[10] WHO, "Coronavirus disease (COVID-19) advice for the public: when and how to use masks. World Health Organization," 2020.

[11] G. LI, Y. FAN, Y. LAI, T. HAN, Z. LI, P. ZHOU, et al., "Coronavirus infections and immune responses," Journal of medical virology, 92, pp. 424-432, 2020.

[12] P. ZHOU, X. YANG, X. WANG, B. HU, L. ZHANG, W. ZHANG, et al., "A pneumonia outbreak associated with a new coronavirus of probable bat origin," Nature, 579, pp. 270-273, 2020.

[13] A. DANDEKAR, S. PERLMAN, "Immunopathogenesis of coronavirus infections: implications for SARS," Nature reviews immunology, 5, pp. 917-927. 2005.

[14] N. ZHU, D. ZHANG, W. WANG, X. LI, B. YANG, J. SONG, et al. A novel coronavirus from patients with pneumonia in China," New England Journal of Medicine, 2020.

[15] T. TANIGUCHI, A. TAKAOKA, "A weak signal for strong responses: interferon-alpha/beta revisited," Nature reviews Molecular cell biology, 2, pp. 378-386, 2001.

[16] O. TAKEUCHI, S. AKIRA, "MDA5/RIG-I and virus recognition," Current opinion in immunology, 20 , pp. $17-$ $22,2008$.

[17] R. WELSH, S. WAGGONER, "NK cells controlling virus-specific T cells: Rheostats for acute vs. persistent infections," Virology, 435, pp. 37-45, 2013.

[18] R. STEINMAN, J. BANCHEREAU, "Taking dendritic cells into medicine," Nature, 449, pp. 419-426, 2007.

[19] M. NOURI-SHIRAZI, E. GUINET, "Exposure to nicotine adversely affects the dendritic cell system and compromises host response to vaccination," The Journal of Immunology, 188, pp. 2359-2370, 2012.

[20] C. KAEWRAEMRUAEN, P. RITPRAJAK, N. HIRANKARN, "Dendritic cells as key players in systemic lupus erythematosus," Asian Pacific journal of allergy, 2019.

[21] L. WU, V. KEWALRAMANI, "Dendritic-cell interactions with HIV: infection and viral dissemination," Nature reviews immunology, 6, pp. 859-868, 2006.

[22] LE BON, D. TOUGH, "Links between innate and adaptive immunity via type I interferon," Current opinion in immunology, 14, pp. 432-436, 2002.

[23] W. LI, M. MOORE, N. VASILIEVA, J. SUI, S. WONGK, M. BERNE, et al., "Angiotensin-converting enzyme 2 is a functional receptor for the SARS coronavirus," Nature, 426, pp. 450-454, 2003.

[24] GLOWACKA, , S. BERTRAM, , M. MÜLLER, P. ALLEN, E. SOILLEUX, S. PFEFFERLESTEFFEN, et al., "Evidence that TMPRSS2 activates the severe acute respiratory syndrome coronavirus spike protein for membrane fusion and reduces viral control by the humoral immune response," Journal of virology, 85, pp. 4122-4134, 2011

[25] W. LIU, M. ZHAO, K. LIU, K. XU, G. WONG, W. TAN, et al., "T-cell immunity of SARS-CoV: Implications for vaccine development against MERS-CoV," Antiviral research, 137, pp. 82-92, 2017.

[26] M. CHENG, C. CHAN, R. CHEUNG, R. BIKKAVILLI, Q. ZHAO, S. AU, et al., "Cross-reactivity of antibody against SARS-coronavirus nucleocapsid protein with IL-11,” Biochem Biophys Res Commun, 338, pp. 1654$60,2005$.

[27] Y. TAN, P. GOH, B. FIELDING, S. S HEN, C. CHOU, J. FU, et al, "Profiles of antibody responses against severe acute respiratory syndrome coronavirus recombinant proteins and their potential use as diagnostic markers," Clinical Diagnostic Laboratory Immunolog, 11, pp. 362-371, 2004.

[28] W. CAO, W. LIU, P. ZHANG, F. ZHANG, J. RICHARDUS, "Disappearance of antibodies to SARSassociated coronavirus after recovery,” N Engl J Med, 357, pp. 1162-3, 2007.

[29] WALLS, M. TORTORICI, B. FRENZ, J. SNIJDERLI, F. REY, F. DIMAIO, et al., "Glycan shield and epitope masking of a coronavirus spike protein observed by cryo-electron microscopy," Nature structural molecular biology, 23, pp. 899, 2016.

[30] WALlS, X. XIONG, Y. PARK, M. TORTORICI, J. SNIJDER, J. QUISPE, et al., "Unexpected receptor functional mimicry elucidates activation of coronavirus fusion," Cell, 176, pp. 1026-1039, 2019.

[31] Y. WATANABE, J. ALLEN, D. WRAPP, J. MCLELLAN, M. CRISPIN, "Site-specific glycan analysis of the SARS-CoV-2 spike," Science, 2020.

[32] L. BAO, W. DENG, H. GAO, C. XIAO, J. LIU, J. XUE, et al., "Rei nfection could not occur in SARS-CoV-2 infected rhesus macaques," BioRxiv, 2020.

[33] H. CHEN, Susceptibility of ferrets, cats, dogs, and different domestic animals to SARS-coronavirus-2," BioRxiv, 2020.

[34] V. MUNSTER, F. FELDMANN, B. WILLIAMSON, N. VAN DOREMALEN, L. PÉREZ-PÉREZ, J. SCHULZ, ,et al., "Respiratory disease and virus shedding in rhesus macaques inoculated with SARS-CoV-2," BioRxiv, 2020.

[35] J. ZHAO, Q. YUAN, H. WANG, W. LIU, X. LIAO, Y. SU, et al., "Antibody responses to SARS-CoV-2 in patients of novel coronavirus disease 2019," Clinical Infectious Diseases, 2020.

[36] W. LIU, M. ZHAO, K. LIU, K. XU, G. WONG, W. TAN, et al., "T-cell immunity of SARS-CoV: Implications for vaccine development against MERS-CoV," Antiviral research, 137, pp. 82-92, 2017.

[37] I. HUNG, K. TO, C. LEE, K. LEE, K. CHAN, W. YAN, R. LIU, et al., "Convalescent plasma treatment reduced mortality in patients with severe pandemic influenza A (H1N1) 2009 virus infection," Clinical Infectious Diseases, 52, pp. 447-456, 2011.

Kurdistan Journal of Applied Research $\mid 4^{\text {th }}$ International Conference on the Health and Medical Science: Medical Researches Improve Life Quality (ICHMS 2020) | 97 
[38] M. HOFFMANN, H. KLEINE-WEBER, S. SCHROEDER, N. KRÜGER, , T. HERRLER, S. ERICHSEN, "SARS-CoV-2 cell entry depends on ACE2 and TMPRSS2 and is blocked by a clinically proven protease inhibitor," Cell, 2020

[39] B. KELLEY, "Developing therapeutic monoclonal antibodies at pandemic pace," Nature biotechnolog, 38, pp. 540-545, 2020.

[40] A. CASADEVALL, L. PIROFSKI, "The convalescent sera option for containing COVID-19," The Journal of clinical investigation, 130 , pp. 1545-1548, 2020.

[41] I. THEVARAJAN, T. NGUYEN, M. KOUTSAKOS, J. DRUCE, CALY, L., C. VAN DE SANDT, et al., "Breadth of concomitant immune responses prior to patient recovery: a case report of non-severe COVID-19," Nature medicine, 26, pp. 453-455, 2020.

[42] FDA, "Recommendations for investigational COVID-19 convalescent plasma. accessed April 9, $2020,2020$.

[43] K. Chen, G. Magri, E. Grasset, "Rethinking mucosal antibody responses: IgM, IgG and IgD join IgA," Nat Rev Immunol, 20, pp. 427-441, 2020.

[44] Z. Eugenia, F. Yvonne, C. Zi, M. Natalieei, "A Dynamic Immune Response Shapes COVID-19 Progression,' Cell Host and Microbe, 27(6), pp. 879-82, 2020.

[45] L. Guo, "Profiling Early Humoral Response to Diagnose Novel Coronavirus Disease (COVID-19)," Clinical Infectious Diseases, 2020.

[46] M. Nisreen, "SARS-CoV-2 Specific Antibody Responses in COVID-19 Patients," preprint (Infectious Diseases (except HIV/AIDS), 2020.

[47] W. Liu, "Evaluation of Nucleocapsid and Spike Protein-Based ELISAs for Detecting Antibodies against SARS-CoV-2," Journal of Clinical Microbiology, 2020.

[48] A. Padoan, "IgA-Ab Response to Spike Glycoprotein of SARS-CoV-2 in Patients with COVID-19: A Longitudinal Study," Clinica Chimica Acta 507, pp. 164-66, 2020.

[49] S. Sanche, YT. Lin, C. Xu, E. Romero-Severson, N. Hengartner, R. Ke, "Early release-High contagiousness and rapid spread of severe acute respiratory syndrome coronavirus," Emerging Infect Dis J, 2020.

[50] MI. Anasir, CL. Poh, "Structural Vaccinology for Viral Vaccine Design,' Front Microbiol, 2019.

[51] K. Dhama, K. Sharun, R. Tiwari, M. Dadar, S. Malik, K. Singh, et al., COVID-19, an emerging coronavirus infection: advances and prospects in designing and developing vaccines, immunotherapeutics, and therapeutics," Hum Vaccin Immunother, 2020.

[52] WHO, "Draft landscape of COVID-19 candidate vaccines," World Health Organisation, 2020.

[53] W. Ning, S. Jian, J. Shibo, D. Lanying, "Subunit Vaccines Against Emerging Pathogenic Human Coronaviruses," Frontiers in Microbiology, 2020.

[54] T. Le, A. Thanh, K. Zacharias, R. Arun, G. Raú, S. Tollefsen, "The COVID-19 vaccine development landscape," Nature Reviews Drug Discovery, 19(5), pp. 305-306, 2020.

[55] V. Gupta, T. Tabiin, K. Sun, A. Chandrashekaran, A. Anwar, K. Yang, et al., SARS coronavirus nucleocapsid immunodominant T-cell epitope cluster is common to both exogenous recombinant and endogenous DNAencoded immunogens," Virology, 347(1), pp. 127-139. 2006.

[56] V. Baruah, S. Bose, "Immunoinformatics-aided identification of $\mathrm{T}$ cell and B cell epitopes in the surface glycoprotein of 2019-nCoV," J Med Virol, 495-500, 2020

[57] NIH Clinical Trial of Investigational Vaccine for COVID-19 Begins | NIH: National Institute of Allergy and Infectious Diseases," [Online]. Available from: https://www.niaid.nih.gov/news-events/nih-cli nical-trial-investigational-vaccine-covid-19-begins. [Accessed on $2020 \mathrm{Apr} 29$ ].

[58] Moderna Ships mRNA Vaccine Against Novel Coronavirus (mRNA-1273) for Phase 1 Study," Moderna, Inc. [Online]. Available from: https://investors.modernatx.com $/ \mathrm{n}$ ews-releases/news-release-details/moderna-ships-mrna-vaccine-against-novel-corona virus-mrna-1273. [Accessed on 2020 Apr. 29].

[59] N. Chau, "The natural history and transmission potential of asymptomatic SARS- CoV-2 infection," Clin. Infect Dis, 2020.

[60] A. Chau, "Indicate high rates of asymptomatic individuals following SARS- CoV-2 exposure," 2020

[61] Q. Long, "Clinical and immunological assessment of asymptomatic SARS- CoV-2 infections," Nat. Med. 26, pp. 1200-1204, 2020.

[62] J. Zhao, "Antibody responses to SARS- CoV-2 in patients of novel coronavirus disease 2019,' Clin. Infect. Dis, 2020.

[63] L. Ni, "Detection of SARS- CoV-2-specific humoral and cellular immunity in COVID-19 convalescent individuals," Immunity, 52, pp. 971-977, 2020.

[64] A. Grifoni, "Targets of T cell responses to SARS- CoV-2 coronavirus in humans with COVID-19 disease and unexposed individuals," Cell, 181, pp. 1489-1501, 2020

[65] C. Shen, "Treatment of 5 critically ill patients with COVID-19 with convalescent plasma," JAMA 323, pp. 1582,2020 .

[66] J. Seow, "Longitudinal evaluation and decline of antibody responses in SARS- CoV-2 infection," Preprint at medRxiv, 2020

[67] A. Sariol, S. Perlman, "Lessons for COVID-19 immunity from other coronavirus infections," Immunity, 2020.

[68] A. Walls, "Structure, function, and antigenicity of the SARS- CoV-2 spike glycoprotein,' Cell 181, pp. 281292, 2020.

[69] S. Jiang, C. Hillyer, L. Du, "Neutralizing antibodies against SARS- CoV-2 and other human coronaviruses," Trends Immunol, 41, pp. 355-359, 2020.

Kurdistan Journal of Applied Research $\mid 4^{\text {th }}$ International Conference on the Health and Medical Science: Medical Researches Improve Life Quality (ICHMS 2020) | 98 
[70] J. Duan, "A human SARS- CoV neutralizing antibody against epitope on S2 protein," Biochem. Biophys. Res. Commun, 333, pp. 186-193, 2005.

[71] M. Coughlin, "Generation and characterization of human monoclonal neutralizing antibodies with distinct binding and sequence features against SARS coronavirus using XenoMouse ${ }^{\circledR}, "$ Virology 361, pp. 93-102, 2007.

[72] M. Tay, C. Poh, L. Rénia, P. MacAry, L. Ng, "The trinity of COVID-19: immunity, inflammation and intervention," Nat. Rev. Immunol, 20, pp. 363-374, 2020.

[73] P. Arunachalam, "T cell- inducing vaccine durably prevents mucosal SHIV infection even with lower neutralizing antibody titers," Nat. Med, 26, pp. 932-940, 2020.

[74] F. Chunmei, "Dendritic cell and T cell responses, Immunity, 53, pp. 1-14, 2020.

[75] K. Remy, "Severe immunosuppression and not a cytokine storm characterize COVID-19 infections," JCI Insight, 2020.

[76] M. Liao, "Single- cell landscape of bronchoalveolar immune cells in patients with COVID-19," Nat. Med, 26, pp. 842-844, 2020.

Kurdistan Journal of Applied Research $\mid 4^{\text {th }}$ International Conference on the Health and Medical Science: Medical Researches Improve Life Quality (ICHMS 2020) | 99 